\title{
Review
}

\section{The next revolution: Popular assemblies and the promise of direct democracy}

\author{
Murray Bookchin \\ Verso Press, London, 2015, 198pp., ISBN: 978-1781685815
}

Contemporary Political Theory (2017) 16, 274-277. doi:10.1057/cpt.2016.14; advance online publication 12 April 2016

The publication of nine of Murray Bookchin's previously unpublished essays from 1990 to 2002 in The Next Revolution: Popular Assemblies and the Promise of Direct Democracy is indeed a timely one. Bookchin has written extensively on anarchism, left-wing history and direct democracy since the 1960s, and his ideas are currently experiencing a renaissance. As political activists, scholars and students are trying to understand the outbursts of political action and direct democratic experimentation in Zucotti Park (Occupy Wall Street), Syntagma Square (the Greek Aganaktismenoi movement), Puerto del Sol (the Spanish Indignados movement) and elsewhere, attention has been drawn to Bookchin's work on assembly democracy. In addition, as prominent scholars such as David Graeber and David Harvey engage in the discussion on the Kurdish movement and their attempts to establish mechanisms of direct democracy and confederalism amidst the war against ISIS, these scholars acknowledge Bookchin's lasting influence on the Kurdish PKK and Abdullah Ocalan (Graeber, 2014; Harvey, 2015). Furthermore, in the recent revival of anarchist perspectives on society and politics, Bookchin is often mentioned as a leading contemporary anarchist, who has succeeded in reinvigorating the anarchist project for the twentieth century. He has done so by incorporating the problems of ecology, capitalist production and urban planning and development into classic anarchist themes of self-management and face-to-face communities (see for instance May, 1994, pp. 51-63).

While reading the nine essays in The Next Revolution, it becomes clear why Bookchin's influence on various different fields is increasing. Bookchin is an imaginative thinker, who leaves few themes untouched. In one essay - 'The Ecological Crisis and the Need to Remake Society' - Bookchin discusses the grievances of contemporary capitalism with 'its imperative, which no entrepreneur or corporation can ignore without facing destruction: growth, more growth and still more growth' (p. 33). Such a grow-or-die capitalism is the real root, in Bookchin's evaluation, of the present ecological crisis, and as such, it cannot be tackled by moral responsibility and individual duties - what Bookchin calls New Age privatism.

(c) 2016 Macmillan Publishers Ltd. 1470-8914 Contemporary Political Theory Vol. 16, 2, 274-277 www.palgrave.com/journals 
In another essay, 'Nationalism and the "National Question", Bookchin tackles the age-old question (for the Left) of nationalism. Bookchin reminds his readers that the core of a progressive left-wing project must be anti-nationalist in character, as the principle of nationalism is intrinsically connected to the development of the modern state with its monarchical and hierarchical tenets (p. 117). In yet another essay, 'Cities: The Unfolding of Reason in History', Bookchin discusses the relationship between the city and the concept of citizenship, between the polis and politics. Here Bookchin argues that, although the city has been instrumental in the development of technology, philosophy, science, literature (in short, of civilization) (pp. 104-105), the identification with the figure of the citizen, which was achieved during the course of the French Revolution, has been heavily under siege from nationalism and individualism (p. 99), whereby the conceptual connection between life in the city and the activity of politics is easily forgotten.

What unites such otherwise quite thematically different essays, is the alternative solution to capitalism, the state and nationalism, which Bookchin identifies. This alternative, which goes under different names such as 'communalism', 'libertarian municipalism' and 'democratic confederalism' is 'based on a network of policymaking popular assemblies with recallable deputies to local and regional confederal councils' (p. 40). The domination of capitalism, nationalism and the state can be countered by 'a new politics of libertarian municipalism: the democratization of municipalities so that they are self-managed by the people who inhabit them, and the formation of a confederation of these municipalities to constitute a counter-power to the nation-state' (p. 137). Throughout the essays, Bookchin tells the story of how such 'democratized municipalities', 'self-managed by the people' have emerged in history. We do not need to go back to the Athenian polis, the Roman plebeian assemblies or the medieval guilds to find such democratic communities. The revolutionary struggles throughout modernity have - according to Bookchin continually produced democratic assemblies, communes, councils and federations. The sections of the French Revolution, the popular clubs of the 1871 Paris Commune, the soviets during the two Russian Revolutions of 1905 and 1917, and the anarchist assemblies of the Spanish Civil War are the hallmarks of this 'communal tradition' within modernity (p. 23). Together, the experiences of assembly-making and direct self-government in these moments constitute 'an explicitly political body of ideas', as 'communalism', according to Bookchin, 'seeks to recover and advance the development of the city in a form that accords with its greatest potentialities and historical traditions' (p. 17). The project of communalism, which these historical events exemplify, 'seeks to radically restructure cities' governing institutions into popular democratic assemblies based on neighbourhoods, towns and villages. In these popular assemblies, 'citizens - including the middle classes as well as the working classes - deal with community affairs on a face-to-face basis, making policy decisions in a direct democracy' (p. 18). Throughout the essays, Bookchin makes some effort to describe the feasibility of such a communal project.

(C) 2016 Macmillan Publishers Ltd. 1470-8914 Contemporary Political Theory Vol. 16, 2, 274-277 275 
In the essay 'The Meaning of Confederalism', Bookchin discusses how the local milieu in villages and towns have often functioned as an organic and natural space for political participation and self-government ( $\mathrm{pp}$. 74-78). In such face-to-face communities, participation and deliberation is possible without becoming merely a clash of already-defined interests. In order to answer the obvious charge that direct democracy is impracticable in the modern world, and that representative democracy is the only possible model of modern democracy, Bookchin shows that the historical instances of communal politics through modernity have developed their own modes of representation and delegation. When collaboration between the self-governing assemblies is necessary, Bookchin shows, such assemblies have constituted citywide and regional councils, where delegates are controlled by the mechanisms of instant recall and imperative mandate: 'The members of these confederal councils are strictly mandated, recallable, and responsible to the assemblies that choose them for the purpose of coordinating and administering the policies formulated by the assemblies themselves' (p. 75). Reading these lines, one is reminded of Karl Marx's ([1871] 1996) famous analysis of the Paris Commune in 'The Civil War in France', in whose interpretation 'communes of every district were to administer their common affairs by an assembly of delegates in the central town, and these delegates were again to send deputies to the national delegation in Paris, each delegate to be at any time revocable and bound the mandate imperitif of his constituency' (Marx, [1871] 1996, p. 185).

The core of Bookchin's communal project, as it is laid out in these essays, consists thus of two political principles: face-to-face self-government and confederalism. Insofar as collectivities can govern themselves sufficiently, they ought to do so; insofar as they cannot, they ought to confederate rather than centralise, bureacratize and professionalize. 'Confederalism is thus a way of perpetuating the interdependence that should exist among communities and regions; indeed, it is a way of democratizing that interdependence without surrendering the principle of local control' (p. 75). Together, these two principles ensure that 'power thus flows from the bottom up instead of from the top' (p. 75).

That Bookchin further develops classical anarchist conceptions of mutual aid societies, horiziontalism and federalism, as initially developed by Proudhon, Kropotkin and Bakunin is relatively clear from his anti-statist communal project. But the similarity with another political thinker, more republican than anarchist, is also visible throughout the essays, namely, Hannah Arendt. In her 1963 book On Revolution, Arendt discusses that she calls 'the lost treasure' of the revolutionary tradition. This lost treasure consists of what Arendt calls the council tradition, namely the appearance of decentralized councils and assemblies throughout the modern revolutions. Arendt (2006) also turns to Paris in 1789 and 1871 and Petrograd in 1905 and 1917 for examples of such council democracy (p. 254). To this list, she adds Thomas Jefferson's proposal of a ward republic, the German workers' councils of 1918-1919, and the Hungarian councils of the revolution in 1956. 
Arendt shares with Bookchin the idea that the council system combines what she calls 'the republican principle', that is, self-government and 'the federal principle', that is, the notion of association, collaboration and bottom-up control (Arendt, 2006, p. 259). Also, in agreement with Bookchin, Arendt (2006) sees the council system as a 'hope for a transformation of the state, for a new government that permits every member of the modern egalitarian society to become a "participator" in public affairs' (pp. 256-257).

For all their stress on actual institutional solutions and real historical precedents, the essays in The Next Revolution should not be regarded as a blueprint for a future communal society: that would contradict the nature of Bookchin's imaginative and, at some points, eclectic thinking. Instead the essays provide the germs of what a non-statist, post-national and anti-capitalist political structure could look like. The specificity of such structure must be left to the engaged citizens themselves, but the principles of direct, assembly-style democracy and confederalism may help such citizens to begin organizing, talking and hoping. This, I suspect, is the source of the current attention to the work of Bookchin, as well as the importance of these newly published essays.

\section{References}

Arendt, H. (2006) On Revolution. New York: Penguin.

Graeber, D. (2014) Why is the world ignoring the revolutionary Kurds in Syria? The Guardian 8 October. Harvey, D. (2015) Reclaiming the city from Kobane to Baltimore. Roar Magazine 26 May.

Marx, K. ([1871] 1996) The civil war in France. In: T. Carver (ed.) Later Political Writings. Cambridge, UK: Cambridge University Press, pp. 163-207.

May, T. (1994) The Political Philosophy of Poststructural Anarchism. Philadelphia, PA: Pennsylvania State University Press.

Benjamin Ask Popp-Madsen

University of Copenhagen, Copenhagen 1165, Denmark bapm@ifs.ku.dk 